\title{
Genomic identification of Pasteurella multocida isolated from turkey flock in Egypt early 2008
}

\author{
S.A.Nassif ${ }^{1 *}$, Hanan M. Ibrahim ${ }^{1}$, Zeinab M. Souror ${ }^{1}$, Arwa H. Elnaggar ${ }^{1}$, \\ Hayam Farouk ${ }^{1}$, A. B. Abd Elrazek ${ }^{2}$, M. M. Yousef ${ }^{3}$, Elham.A. Elebiary ${ }^{1}$ \\ ${ }^{l}$ Central laboratory for evaluation of veterinary biologics, ${ }^{2}$ Faculty of Agriculture, Ain-Shams \\ University, ${ }^{3}$ Veterinary serum and vaccine research institute, Cairo, Egypt.
}

\begin{abstract}
Molecular detection and differentiation of Pasteurella multocida strain involved in a separate fowl cholera outbreak in a turkey flock farm located in El-Menofia Governorate, Egypt early 2008 was investigated. The isolated strain was compared with an Egyptian Pasteurella multocida isolate that was previously isolated from turkey flock during last decade besides four vaccinal strain (A:5, A:8, A:9 and D:2) on phenotypic and genotypic characterization basis. Phenotypically all the strains were similar as all the strains produce non haemolytic colonies on blood agar, and all the strains revealed similar biochemial behaviour. On the other hand, the genomic typing of all the stains using rep-PCR techniques [repetitive BOX elements, enterobacterial repetitive intergenic consensus (ERIC) and repetitive extragenic palindromic (REP) polymerase chain reaction (PCR)] differentiated the six Pasteurella multocida strains into six different profiles. The molecular identity between the Pasteurella multocida 2008 strain and the previously isolated strain was $76.6 \%$ and were ranged from $65.2 \%$ to $79.2 \%$ with the 4 vaccinal strains. These results reported the continuous mutations of the field Pasteurella multocida strains among poultry flocks in Egypt indicating the urgent need for the frequent and continuous molecular epidemiological investigations of fowl cholera outbreaks in various poultry flocks to detect these new strains and update the fowl cholera vaccines.
\end{abstract}

Fowl cholera, caused by Pasteurella multocida, occurs sporadically or enzootically in most countries of the world wherever intensive poultry production occurs, and is known as a bacterial disease of major economic importance due to its high mortality (Rimler and Glisson, 1997). Currently, incidences of fowl cholera along with other bacterial diseases are on the increase despite vaccination and proper medication as a sequel of various incriminating factors (Jonas et al., 2001). Conventional methods of disease diagnosis depend on isolation, identification and differentiation by employing bacteriological techniques, serotyping, pathogenicity tests, antibiotic sensitivity tests and biochemical tests (Rimler and Glisson, 1997). However, these techniques are laborious, time consuming and not free from certain limitations. The limitations of currently employed techniques have led to significant problems in understanding the disease outbreaks, origin and transmission of pathogens, the virulence characteristics of the organism and in determining disease incidence and economic importance. DNA-based techniques, which are rapid, specific and highly sensitive, are efficiently employed for early detection and differentiation of various strains of different micro-organisms from single/different outbreaks (Blackall and Miflin, 2000; Biswas et al., 2004) The heterogeneous diversities of avian $P$. multocida strains can be well differentiated with the use of molecular biological techniques such as restriction endonuclease analysis (REA)(Wilson et al., 1993), single primer PCR (Dabo et al., 2000), enterobacterial repetitive intergenic consensus (ERIC -PCR ) (Loubinoux et al., 1999), and repetitive extragenic palindromic (REP-PCR) (Townsend et al., 1997). In the present investigation of fowl cholera outbreak in a turkey flock, the applicability and efficiency of conventional as well as novel molecular methods for their ability to identify and characterize $P$. multocida strains were studied, compared with the standard P.multocida serotypes.

\section{Materials and methods}

Bacterial isolation. A fowl cholera outbreak that occurred within a 14 week old turkey flock in a single private turkey farm, at El-Menofia governorate during Jan .2008, was investigated Bacterial cultures isolated from the heart blood and bone marrow of dead birds were maintained

\footnotetext{
* Corresponding author. Tel.: +20 0160448804 ;

E-mail address: samirnasif69@yahoo.com

(Samir Nasif)
} 
on blood agar slants as well as freeze-dried ampoules for further studies.

Conventional identification. All strains [The recently isolated one which designated as T08 besides a previously isolated and identified $P$. multocida strain T90 and four standard P.multocida vaccinal strains (A:5,A:8,A:9 and $\mathrm{D}: 2)]$ were subjected for identification based on cultural, morphological and biochemical characteristics as described in the standard bacteriological methods (Cruickshank et al., 1975). The bacterial cultures identified as $P$. multocida were further classified as capsular and somatic serogroups based on an indirect haemagglutination assay (Carter, 1955) and an agar gel precipitation test (Heddleston et al., 1972), respectively.

Pathogenicity test. All strains of $P$.multocida were grown for $18 \mathrm{~h}$ in a shaker-come-incubator at $37^{\circ} \mathrm{C}$ in brain heart infusion (BHI) broth. About $0.2 \mathrm{ml}$ each culture containing approximately $2.4 \times 10^{8}$ colony forming units $/ \mathrm{ml}$ was inoculated into each of three mice by the intra- peritoneal route and observed for $72 \mathrm{~h}$ to study the mortality pattern .Re-isolation of organisms were carried out on a blood agar plate using heart blood collected from dead mice, and an impression smear from the liver was prepared for observation following the Giemsa method of staining.

DNA extraction. Genomic DNA of all strains was extracted following the method described by (Wilson, 1987). The concentration of DNA was measured spectrophotometrically at $260 \mathrm{~nm}$.

\section{Enterobacterial repetitive intergenic consensus ERIC-PCR. This PCR was} conducted using primers targeting palindromic sequences of ERIC according to (Versalovic et al., 1991) as shown in table 1.The ERIC-PCR components volumes and concentrations and the reaction conditions are shown in (Table 2, 3).

Repetitive extragenic palindromic (REP)PCR. The assay was performed using oligonucleotide primers targeting REP sequences of bacteria according to (Versalovic et al., 1991.) as shown in table 1.The REP-PCR components volumes and concentrations and the reaction conditions are shown in Table 2,3 ..

Repetitive BOX-PCR. The assay was performed using oligonucleotide primers targeting BOX sequences of bacteria according to (Versalovic et al., 1991) as shown in Table 1. The BOX-PCR components volumes and concentrations and the reaction conditions are shown in Table 2, 3 .

All three types of PCR-based typing methods were performed three times- using $\mathrm{T}$ gradient Thermal cycler of Biometra co. - to ensure that strains were correctly assigned to respective patterns.Assigning of the profile produced by each strain was denoted as distinct when their PCR types differed by (1) band .PCR profiles generated by various typing tools were analyzed by composing a data matrix built on the presence (+) or absence (-) of any fragment appearing in each strain. The size of bands that differed by $5 \%$ on the different gels were considered as the same band.Cluster analysis was performed using the un-weighed-pair-group method with arithmetic linkages, as per the method of Li (1981), to identify and establish the relationship among various strains, if any.

\section{Results}

The observed clinical signs in the affected turkey flock were anorexia, dullness and depression with ruffled feathers, shallow rapid respiration and diarrhea at later stages before death. The mortality rate was $1 \%$ daily with cumulative mortality rate of $10 \%$. The flock was of 95 day old at the beginning of infection and was vaccinated once at the $65^{\text {th }}$ day old with the local inactivated fowl cholera vaccine via subcutaneous route at a dose of $0.5 \mathrm{ml}$. The Postmortem examination of acutely dead birds revealed generalized septicemia, swollen liver with necrotic foci and petechial haemorrhages. Haemorrhages on subepicardial and subserosal areas were prominent. Congestion of lungs and mild enlargement of kidneys with distended tubules were also observed.

Conventional identification. Small glistening mucoid dew drop like colonies were found on blood agar plates after incubation at $37^{\circ} \mathrm{C}$ for 18 $\mathrm{h}$, and Gram-negative, cocco-bacilli appeared following Gram's stain and bipolar organisms in Giemsa staining. All strains produced indole, positive for catalase, oxidase and the nitrate reduction test. No reaction was seen with citrate, methyl red and Voges/Proskauer tests and gelatin liquefaction tests. The organisms did not grow on McConkey's agar and were found to be non-haemolytic on blood agar. Glucose, fructose, galactose, mannitol and sucrose were fermented and none of the strains reacted with salicin, raffinose, inositol and rhamnose. Conventional methods of capsular and somatic serotypingidentified the $\mathrm{T} 08$ isolate of turkey as well as the T90 as P. multocida serogroup A:1. 
Table (1): List of primer sequences used in PCR techniques.

\begin{tabular}{|c|c|c|c|}
\hline $\begin{array}{l}\text { Serial } \\
\text { number }\end{array}$ & $\begin{array}{c}\text { Type of } \\
\text { PCR }\end{array}$ & Primer sequences & Reference \\
\hline 1 & REP-PCR & $\begin{array}{l}\text { REP1R-IDt, 5'-NNN NCG NCG NCA TCN GGC- } \\
\text { 3' } \\
\text { REP2-IDt, 5'-NCG NCT TAT CNG GCC TAC-3' }\end{array}$ & Versalovic et al., (1991) \\
\hline 2 & ERIC-PCR & $\begin{array}{l}\text { ERIC1R,5'- ATG TAA GCT CCT GGG GAT CAC- } \\
\text { 3' } \\
\text { ERIC2, 5'-AAG TAA GTG ACT GGG GTG AGC } \\
\text { G-3' }\end{array}$ & Versalovic et al., (1991) \\
\hline 3 & BOX-PCR & $\begin{array}{l}\text { BOX A1R 5'- CTA CGG CAA GGC GAC GCT } \\
\text { GAC G -3, }\end{array}$ & Versalovic et al., (1991) \\
\hline
\end{tabular}

Table (2): Concentration of various components used in rep-PCR (QIAGEN PCR kit).

\begin{tabular}{lllll}
\hline Sr. No & Components & BOX-PCR & ERIC-PCR & REP-PCR \\
\hline $\mathbf{1 .}$ & PCR Master mix $(2 \mathrm{X})$ & $12.5 \mu \mathrm{l}$ & $12.5 \mu \mathrm{l}$ & $12.5 \mu \mathrm{l}$ \\
$\mathbf{2}$ & Primer $(10 \mathrm{pmol} / \mu \mathrm{l})$ & $1.0 \mu \mathrm{l}$ & $1.0 \mu \mathrm{l}$ each & $1.0 \mu \mathrm{l}$ each \\
$\mathbf{3}$ & DNA Template $(30 \mathrm{ng} / \mu \mathrm{l})$ & $3.0 \mu \mathrm{l}$ & $3.0 \mu \mathrm{l}$ & $3.0 \mu \mathrm{l}$ \\
$\mathbf{4}$ & Distilled Water & $8.5 \mu \mathrm{l}$ & $7.5 \mu \mathrm{l}$ & $7.5 \mu \mathrm{l}$ \\
\hline
\end{tabular}

Table (3): Thermal cycling protocol for rep-PCR.

\begin{tabular}{|c|c|c|c|c|c|c|}
\hline Sr.No. & $\begin{array}{c}\text { PCR } \\
\text { Category }\end{array}$ & $\begin{array}{c}\text { Initial } \\
\text { denaturation }\end{array}$ & Denaturation & Annealing & Extension & $\begin{array}{c}\text { Final } \\
\text { extension }\end{array}$ \\
\hline 1 & BOX-PCR & $94^{\circ} \mathrm{C}, 5 \mathrm{~min}$ & $\begin{array}{l}94^{\circ} \mathrm{C} \\
1 \mathrm{~min}\end{array}$ & $\begin{array}{l}40^{\circ} \mathrm{C} \\
2 \mathrm{~min}\end{array}$ & $\begin{array}{l}72^{\circ} \mathrm{C} \\
2 \mathrm{~min}\end{array}$ & $\begin{array}{l}72^{\circ} \mathrm{C}, \\
10 \mathrm{~min}\end{array}$ \\
\hline 2 & ERIC-PCR & $94^{\circ} \mathrm{C}, 5 \mathrm{~min}$ & $\begin{array}{l}94^{\circ} \mathrm{C}, \\
1 \mathrm{~min}\end{array}$ & $\begin{array}{l}\text { ted for } 35 \mathrm{cyc} \\
52^{\circ} \mathrm{C} \\
1.5 \mathrm{~min}\end{array}$ & $\begin{array}{l}65^{\circ} \mathrm{C}, \\
8 \mathrm{~min}\end{array}$ & $\begin{array}{l}65^{\circ} \mathrm{C}, \\
16 \mathrm{~min}\end{array}$ \\
\hline 3 & REP-PCR & $94^{\circ} \mathrm{C}, 5 \mathrm{~min}$ & $\begin{array}{ll}94^{\circ} \mathrm{C}, & \mathrm{Re} \\
1 \mathrm{~min} & \\
& \mathrm{Re}\end{array}$ & $\begin{array}{l}\text { ted for } 40 \mathrm{cy} \\
52^{\circ} \mathrm{C} \\
1 \mathrm{~min} \\
\text { ted for } 40 \mathrm{cyc}\end{array}$ & $\begin{array}{l}65^{\circ} \mathrm{C}, \\
8 \mathrm{~min}\end{array}$ & $\begin{array}{l}65^{\circ} \mathrm{C}, \\
16 \mathrm{~min}\end{array}$ \\
\hline
\end{tabular}

Pathogenicity test. Each examined strain of P.multocida was found to be pathogenic to mice, causing mortality within $24 \mathrm{~h}$. No significant variation in mortality pattern was observed. Reisolated colonies showed similar characteristics of $P$. multocida, and impression smears revealed typical bipolarity of the organism.

ERIC -PCR. Generated amplified products of 13 bands, which were in the range of $2.225 \mathrm{~kb}$ to $389 \mathrm{bp}$, categorized the 6 strains into six different profiles (Figure 1 and table 4) The number of bands amplified in different samples by ERIC-PCR were varied from 10 to 12 with the band frequency ranging from 0.167 to 1.000 . The bands of ERIC-PCR were $15.4 \%$ polymorphic, $15.4 \%$ unique and $69.2 \%$ monomorphic.

REP- PCR. Generated amplified products of 12 bands, which were in the range of $1.870 \mathrm{~kb}$ to $235 \mathrm{bp}$, categorized the 6 strains into six different profiles (Figure 2 and table 5) The number of bands amplified in different samples by REP-PCR were varied from 6 to 10 with the band frequency ranging from 0.167 to 1.000 . The bands of REP-PCR were $58.3 \%$ polymorphic, $16.7 \%$ unique and $25 \%$ monomorphic.

BOX- PCR. Generated amplified products of 12 bands, which were in the range of $1.315 \mathrm{~kb}$ to $155 \mathrm{bp}$, categorized the 6 strains into six different profiles (Figure 3 and table 6) The number of bands amplified in different samples by BOX-PCR were varied from 6 to 7 with the band frequency ranging from 0.167 to 0.833 . The bands of BOX-PCR were $83.3 \%$ polymorphic and $16.7 \%$ unique. 
Table (4): Plus / Minus data for ERIC- PCR analysis gel image.

\begin{tabular}{ccccccccc}
\hline MW & Lane1 & Lane2 & Lane3 & Lane4 & Lane5 & Lane6 & Frequency & Polymorphism \\
\hline $\mathbf{2 2 2 5}$ & - & - & + & + & + & + & 0.667 & Polymorphic \\
$\mathbf{1 8 7 0}$ & + & + & + & + & + & + & 1.0 & Monomorphic \\
$\mathbf{1 3 5 6}$ & - & - & + & - & - & - & 0.167 & Unique \\
$\mathbf{1 1 3 0}$ & + & + & + & + & + & + & 1.0 & Monomorphic \\
$\mathbf{9 5 0}$ & + & + & + & + & + & + & 1.0 & Monomorphic \\
$\mathbf{9 2 0}$ & + & + & + & + & + & + & 1.0 & Monomorphic \\
$\mathbf{8 6 0}$ & + & + & + & + & + & + & 1.0 & Monomorphic \\
$\mathbf{6 7 0}$ & + & + & + & - & + & - & 0.667 & Polymorphic \\
$\mathbf{6 3 0}$ & + & + & + & + & + & + & 1.0 & Monomorphic \\
$\mathbf{5 8 0}$ & + & + & + & + & + & + & 1.0 & Monomorphic \\
$\mathbf{5 1 0}$ & + & + & + & + & + & + & 1.0 & Monomorphic \\
$\mathbf{4 3 0}$ & + & - & - & - & - & - & 0.167 & Unique \\
$\mathbf{3 8 9}$ & + & + & + & + & + & + & 1.0 & Monomorphic \\
& 11 & 10 & 12 & 10 & 11 & 10 & & \\
\hline
\end{tabular}

Table (5): Plus / Minus data for REP- PCR analysis gel image.

\begin{tabular}{ccccccccc}
\hline MW & Lane1 & Lane2 & Lane3 & Lane4 & Lane5 & Lane6 & Frequency & Polymorphism \\
\hline $\mathbf{1 8 7 0}$ & + & - & + & - & + & + & 0.667 & Polymorphic \\
$\mathbf{1 5 6 8}$ & + & - & + & - & + & + & 0.667 & Polymorphic \\
$\mathbf{1 3 5 0}$ & + & + & + & + & + & + & 1.0 & Monomorphic \\
$\mathbf{1 2 7 0}$ & + & + & + & + & + & + & 1.0 & Monomorphic \\
$\mathbf{1 1 5 0}$ & - & + & + & + & + & + & 0.833 & Polymorphic \\
$\mathbf{1 0 2 8}$ & + & - & - & - & - & - & 0.167 & Unique \\
$\mathbf{8 9 5}$ & - & + & + & + & + & + & 0.833 & Polymorphic \\
$\mathbf{5 2 0}$ & - & + & + & + & - & - & 0.500 & Polymorphic \\
$\mathbf{3 6 5}$ & + & + & + & + & + & + & 1.0 & Monomorphic \\
$\mathbf{3 3 5}$ & - & + & + & + & - & + & 0.667 & Polymorphic \\
$\mathbf{3 0 0}$ & - & - & - & - & + & - & 0.167 & Unique \\
$\mathbf{2 3 5}$ & - & + & + & + & - & - & 0.500 & Polymorphic \\
& 6 & 8 & 10 & 8 & 8 & 8 & & \\
\hline
\end{tabular}

Table (6): Plus/ Minus data for BOX - PCR analysis gel image.

\begin{tabular}{ccccccccc}
\hline MW & Lane1 & Lane2 & Lane3 & Lane4 & Lane5 & Lane6 & Frequency & Polymorphism \\
\hline $\mathbf{1 3 1 5}$ & - & - & - & - & + & - & 0.167 & Unique \\
$\mathbf{1 0 5 6}$ & + & + & - & + & - & + & 0.667 & Polymorphic \\
$\mathbf{9 8 0}$ & - & - & + & - & + & - & 0.333 & Polymorphic \\
$\mathbf{8 7 8}$ & + & - & - & + & - & + & .500 & Polymorphic \\
$\mathbf{8 7 0}$ & + & + & + & - & - & - & .500 & Polymorphic \\
$\mathbf{7 5 0}$ & - & - & - & - & + & - & .167 & Unique \\
$\mathbf{6 4 5}$ & - & - & - & + & + & + & .500 & Polymorphic \\
$\mathbf{3 6 0}$ & + & + & + & + & - & + & 0.833 & Polymorphic \\
$\mathbf{3 4 3}$ & + & + & + & + & - & + & .833 & Polymorphic \\
$\mathbf{3 1 0}$ & - & - & - & + & - & + & 0.333 & Polymorphic \\
$\mathbf{2 9 2}$ & + & + & + & + & - & + & 0.833 & Polymorphic \\
$\mathbf{1 5 5}$ & - & + & + & - & - & - & 0.333 & Polymorphic \\
& 6 & 6 & 6 & 7 & 4 & 7 & & \\
\hline
\end{tabular}




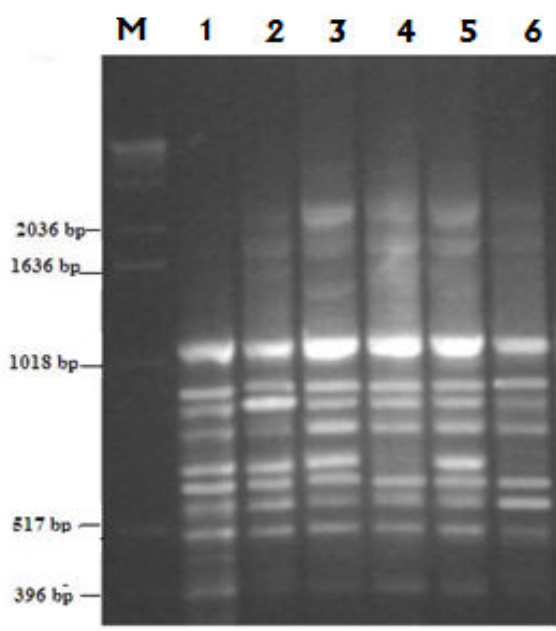

Fig. 1

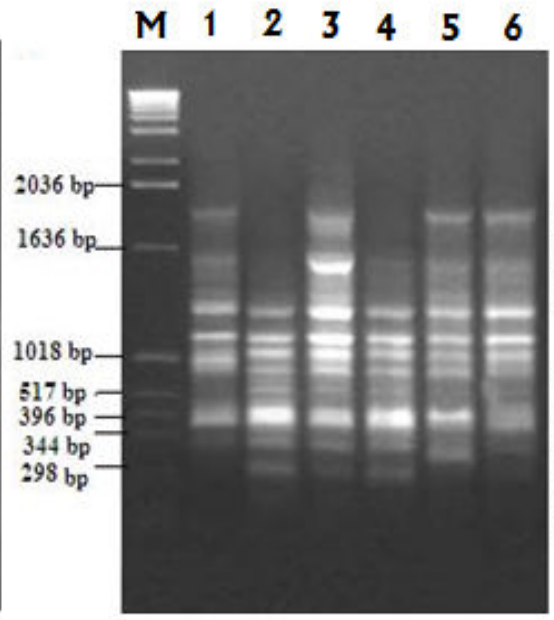

Fig.2

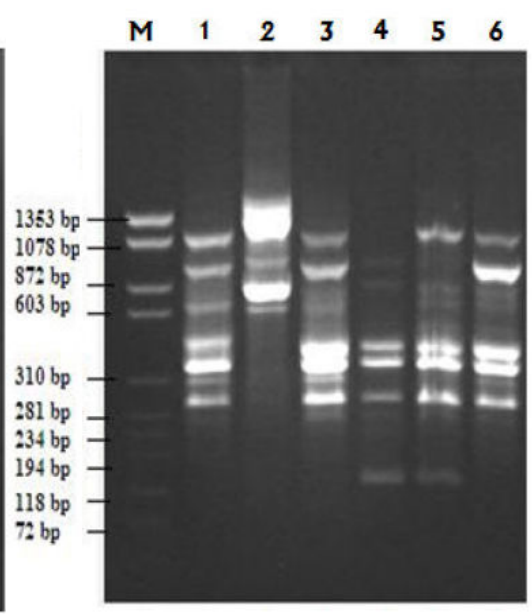

Fig.3

Fig (1): ERIC-PCR fingerprinting profiles of P.multocida strains Lane M, DNA molecular weight marker X of Roche Applied Science; lane 1 represent the recent 2008 P.multocida strain; Lane 2 represent the previously isolated $P$.multocida strain ;Lanes 3 to 6 represent the vaccinal P.multocida strains.

Fig (2): REP-PCR fingerprinting profiles of $P$. multocida strains Lane M, DNA molecular weight marker $X$ of Roche Applied Science; lane 1 represent the recent 2008 P.multocida strain; Lane 2 represent the previously isolated $P . m u l t o c i d a$ strain; Lanes 3 to 6 represent the vaccinal $P$. multocida strains.

Fig (3): BOX -PCR fingerprinting profiles of $P$. multocida strains Lane M, DNA molecular weight marker IX of Roche Applied Science Lane 1 represent the recent 2008 P. multocida strain; Lane 2 represent the previously isolated P.multocida strain; And Lanes 3 to 6 represent the vaccinal P.multocida strains.
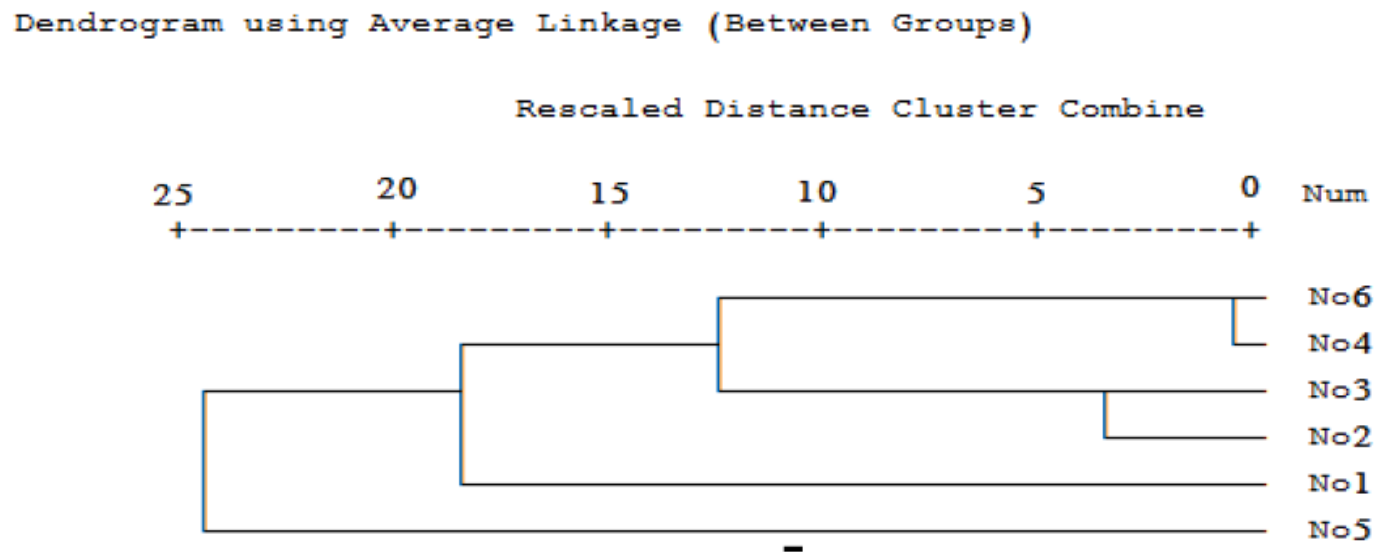

Fig (4): Combined cluster analysis of ERIC-PCR. REP-PCR and BOX- PCR

Table (7): The Proximity Matrix.

\begin{tabular}{ccccccc}
\hline \multirow{2}{*}{ Case } & \multicolumn{7}{c}{ Matrix } \\
\cline { 2 - 7 } & No 6 & No 5 & No 4 & No 3 & No 2 & No 1 \\
\hline No 6 (A:5) & 1.000 & .750 & .920 & .792 & .776 & .792 \\
No 5 (D:2) & .750 & 1.000 & .667 & .745 & .638 & .652 \\
No 4 (A:9) & .920 & .667 & 1.000 & .792 & .857 & .708 \\
No3 (A:8) & .792 & .745 & .792 & 1.000 & .885 & .745 \\
No 2 (T90) & .776 & .638 & .857 & .885 & 1.000 & .766 \\
No 1 (T08) & .792 & .652 & .708 & .745 & .766 & 1.000 \\
\hline
\end{tabular}


Overall Cluster Analysis. Data from all the three rep-PCR fingerprints were pooled together to generate consensus tree. Dendogram generated by combining results obtained from all these primers showed large degree of genetic heterogeneity among the studied P.multocida strains (Fig 4 and Table 7). The recent 2008 P.multocida strain (T 08) showed $76.6 \%$ similarity with the previously isolated P.mulocida strain (T90) and $65.2 \%, 70.8 \%, 74.5 \%$ and $79.2 \%$ with the P.multocida vaccinal strains D:2, A:9, A:8 and A:5; respectively.

\section{Discussion}

The epidemiology of fowl cholera outbreaks is complex (Christensen and Bisgaard, 2000). Traditional methods are only of limited use in studies of such outbreaks especially where there is an involvement of multiple strains of P.multocida. In the present investigation, isolation of P.multocida by standard bacteriological methods from an outbreak in a turkey flock, despite prophylactic vaccination practices with a single dose of $0.5 \mathrm{ml} / \mathrm{bird}$-at the 65th day old ie since one month ago-with the local inactivated fowl cholera vaccine. These results are in agreement with that obtained by (Jonas et al., 2001) as they revealed presence of fowl cholera outbreaks among poultry flocks previously vaccinated with killed fowl cholera vaccines. The isolated T08 strain was compared with an Egyptian P.multocida isolate (T90) that was previously isolated from turkey flock during last decade besides 4 vaccinal strain (A:5, A:8, $\mathrm{A}: 9, \mathrm{D}: 2)$ on phenotypic and genotypic characterization basis.

Phenotypically, the two P.multocida field strains besides the 4 P.multocida vaccinal strains had similar cultural and morphological characteristics. Moreover, biochemical and pathogenicity tests have not yet been found to be useful in differentiation between the examined strains. As the two field strains shared similar capsular and somatic antigens (serogroup A:1), we could not differentiate them by the conventional methods. This result agreed with that noticed earlier that serotyping is not a useful means of establishing the relationship between strains of $P$ multocida (Blackall et al., 1995).,

In the current study PCR-based typing techniques such as ERIC-PCR, REP-PCR and BOX- PCR are utilized to differentiate between the two field P.mulocida isolates and the 4 vaccinal strains included in the local inactivated oil adjuvenated fowl cholera vaccine, the results of each test revealed presence of significant differences between the recent field isolate $\mathrm{T} 08$, the other field isolate T90 and the other 4 vaccinal strains. Data from all the three rep-PCR fingerprints were pooled together to generate consensus tree. Dendogram generated by combining results obtained from all the 3 PCR based techniques showed large degree of genetic heterogeneity among the studied P.multocida strains (Fig. 4 and Table 7). The recent T08 P.multocida strain showed $76.6 \%$ similarity with the previously isolated P.mulocida T90 strain and $65.2 \%, 70.8 \%, 74.5 \%$ and $79.2 \%$ with the P.multocida vaccinal strains D:2, A:9 ,A:8 and A:5 ; respectively indicating the continual mutation of the P.multocida strains among the poultry flocks-including the turkey flock under study - under field condition despite the prophylactic vaccination with the local inactivated fowl cholera vaccine .These results proved that the diagnosed fowl cholera outbreak among turkey flock under study was due to infection with a mutant strain of P.multocida differed from those included in the vaccine .These results proved the urgent need for frequent and continuous molecular epidemiological investigations of fowl cholera outbreaks among poultry flocks in Egypt with continual isolation, identification and genotyping of P.multocida strains. Then the collected P.multocida strains should always compared with the vaccinal strains with edition of the predominant mutant strains to the vaccine. On the other hand further studies should be conducted on the application of the current local inactivated fowl cholera vaccine in turkey flocks, ducks and other poultry species other than chickens to determine the optimal dose and regime of vaccination for each species. The importance of selecting the right molecular typing method, which seems to be very crucial in studying either single or multiple P.multocida outbreaks. In such cases, Shivachandra et al., (2005) reported that PCR-based typing methods, especially those that are based on repetitive consensus sequences, are found to be highly reproducible and discriminatory in identifying multiple strains and establishing relationship between outbreaks in a given region as well as between regions. ERIC-PCR, REP-PCR and BOX -PCR were found to have a high discriminatory ability (D_/0.89). In addition, Loubinoux et al., 1999; Amonsin et al., (2002) found that these methods are rapid, reproducible, and easy to perform. The present results also 
recognized the ability of these tools to provide reproducible results with a satisfactory discriminatory power, as all strains in the current study were differentiated. Overall, the current results signify that PCR-based amplification of repetitive regions of the genome has greater utility for investigating the epidemiology of fowl cholera and conducting outbreak investigations. Moreover, our evaluations also suggests that future investigations of fowl cholera outbreaks could benefit from the use of both PCR-based identification and typing techniques, conducted in parallel with conventional methods of confirmatory diagnosis to study infectious agent in a disease outbreak.

\section{References}

Amonsin, A.; Wellehan, J. F. X.; Li, L.L.; Laber, J. and Kapur, V. (2002): DNA fingerprinting of Pasteurella multocida recovered from Avian sources. J. Clin. Microbiol., 40(8):3025-3031.

Biswas, A.; Shivachandra, S. B.; Saxena, M. K.; Kumar, A. A.; Singh, V. P. and Srivastava, S. K. (2004): Molecular variability among strains of Pasteurella multocida isolated from an outbreak of haemorrhagic septicaemia in India. Vet. Res. Comm., 28(4):287- 298.

Blackall, P. J. and Miflin, J. K. (2000): Identification and typing of Pasteurella multocida: a review. Avian Pathol., 29:271-287.

Blackall, P. J.; Pahoff, J. L.; Marks, D.; Fegan, N. and Morro C. J. (1995): Characterization of Pasteurella multocida isolated from fowl cholera outbreaks on turkey farms. Australian Vet. J., 72:135-138.

Carter, G. R. (1955): Studies on Pasteurella multocida: a haemagglutination test for the identification of serological types. Am. J. Vet. Res., 16:481- 484.

Christensen, J. P. and Bisgaard, M. (2000): Fowl cholera. Scientific and technical review Office International des Epizooties, 19(2):626-637.

Cruickshank, R.; Duguid, J. P.; Marmion, B. P. and Swain, R.H.A. (1975): Medical Microbiology $2^{\text {nd }}$ edn, Vol. 1. Edinburgh: Churchill Livingstone.

Dabo, S. M.; Confer, A. W. and Lu, S. Y. (2000): Single primer polymerase chain reaction fingerprinting for Pasteurella multocida strains from laboratory rabbits. Am. J. Vet. Res., 61(3):305-309.

Heddleston, K. L.; Gallagher, J. E. and Rebers, P. A. (1972): Fowl cholera: gel diffusion precipitation test for serotyping Pasteurella multocida from avian species. Avian Dis., 16:925-936.

Jonas, M., Morishita, T.Y., Angrick, E.J. and Fahya, J. (2001). Characterization of nine Pasteurella multocida strains from avian cholera outbreaks in Indonesia. Avian Dis., 45, 34- 42.

Li, W. H. (1981): Simple method for constructing phylogenetic trees from distance matrices. Proc. Nat. Acad. Sci., USA, 78:1085-1089.

Loubinoux, J.; Lozuiewski, A.; Lion, C.; Garin, D.; Weba, M. and Faou, L. E. A. (1999): Value of ERIC-PCR for study of Pasteurella multocida strains isolated from mouth of dogs. J. Clin. Microbiol., 37:2488-2492.

Rimler, R. B. and Glisson, J. R. (1997): Fowl cholera. In B.W. Calnek, H.J.Barnes, C.W. Beard, L.R. Mcdougald and Y.M. Saif (Eds.), Diseases of Poultry 10th edn (pp. 143 159). Ames, IA: State University Press.

Shivachandra, S. B.; Kumar, A. A.; Gautam, R.; Saxena, M. K.; Chaudhuri, P. and Srivastava, S. K. (2005): Detection of multiple strains of Pasteurella multocida in fowl cholera outbreaks by polymerase chain reaction-based typing. Avian Pathol., 34(6):456-462.

Townsend, K. M.; Dawkins, H. J. S. and Papadimitriou, J. M. (1997): REP-PCR analysis of Pasteurella mutocida isolates that cause haemorrhagic septicaemia. Res.Vet. Sci., 63:151-155.

Versalovic, J.; Koeuth, T. and Lupski, J. R. (1991): Distribution of repetitive DNA sequences in eubacteria and application of fingerprinting of bacterial genomes. Nucleic Acids Res., 19, 6823 - 6831 .

Wilson, M. A.; Morgan, M. J. and Barger, G. E. (1993): Comparison of DNA fingerprinting and serotyping for identification of avian Pasteurella multocida isolates. J. Clin. Microbiol., 31, 255 - 259.

Wilson, K. (1987): Preparation of genomic DNA from bacteria. In F.M. Ausubal, R. Brent, R.L. Kirston, D.D., Moore, J.G. Seidman, J.A.Smith and K. Struhe (Eds.), Current Protocols in Molecular Biology Vol. 1 (pp. 2.4.1 2.4.2). New York: John Wiley and Sons.

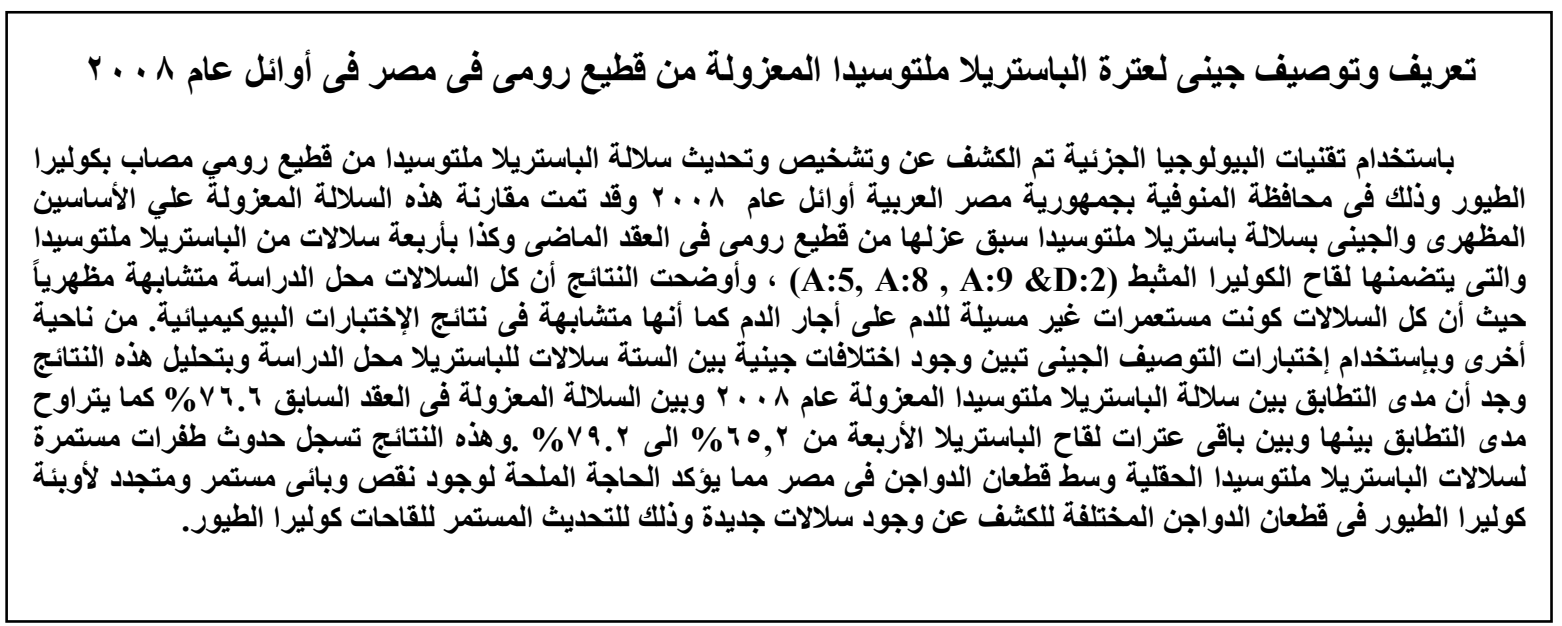

